\title{
Examining Export-Led Growth in Sub-Saharan Africa and China
}

\author{
Joe Zimmerman ${ }^{1}$ and Brian Wheaton ${ }^{2}$ \\ ${ }^{1}$ University School of Milwaukee, Milwaukee, WI, USA \\ ${ }^{2}$ Harvard University, Cambridge, MA, USA
}

\section{$\underline{\text { ABSTRACT }}$}

Export-led growth is an economic hypothesis that links the level of a nation's exports to economic growth in that country. Seen primarily as a model for low-income, developing nations to accelerate convergence as China began to do in the 1980s, the hypothesis theoretically still stands for developed nations. However, there exists significant discussion and doubt as to the strength and causality of the relationship between exports and growth, especially after a nation has industrialized and established itself as a major exporter. This paper examines and compares the effect of exports, imports, and net exports on economic growth for a set of low-income nations (Sub-Saharan Africa) and a country that has already undergone a significant economic transformation (China, at the provincial level). I regress the share of exports, imports, and net exports against GDP growth for Sub-Saharan African nations and Chinese provinces, and use instrumental variables to check for robustness. I find that while in Sub-Saharan Africa the share of exports and net exports exhibit a positive relationship with economic growth, higher shares of exports and net exports in China are associated with lower economic growth. This suggests that export-led growth is valid in Sub-Saharan Africa, but no longer is in China. I pose two potential explanations for this outcome in China: inefficient trade with low-income nations or decreasing trade with high-income nations. Regressions of China's exports to these two types of economies over time indicate that the latter is the primary cause of the distinction in the effect of exports.

\section{Introduction}

The rapid development of China's economy over the past 4 decades has been well documented and studied across the globe as a model of successful convergence. Running a consistent trade surplus since the early 1990s, it has often been speculated that high exports have been critical to China's economic growth, a factor that some other developing nations have attempted to imitate. I evaluate the association relating trade to economic growth as it applies to both individual provinces of China and the nations of sub-Saharan Africa, a region comprised almost entirely of lowincome developing countries. More precisely, I study the contribution to GDP of exports and imports and their effects on the overall growth of GDP in these nations from the 1990s until recent years.

I use data on GDP and its components for Sub-Saharan African nations from the Penn World Table to run OLS regressions relating the share of exports, imports, and net exports in GDP to national economic growth. I find that years with higher shares of exports and net exports are associated with higher GDP growth, while the share of imports did not have a significant relationship with GDP growth. To check for robustness, I run instrumental variable regressions using a country's membership in the World Trade Organization as an instrument and again find that increased shares of exports and net exports in GDP are associated with faster economic growth. Additionally, the IV regressions showed that years with higher shares of imports were associated with years of lower economic growth. Next, I use provincial-level Chinese data from the Chinese National Bureau of Statistics to run regressions relating shares of exports, imports, and net exports to Gross Regional Product growth within the Chinese provinces. I find that higher shares of each of the three measures are associated with lower economic growth across the provinces. I used the Chinese Free Trade Zones as an instrument in my IV regressions, which showed that higher shares of both imports 
and exports were associated with lower levels of economic growth. This evidence supports the theory of export-led growth in Sub-Saharan Africa but suggests that exports, in addition to imports, may now be detrimental to Chinese growth.

Next, I examine the potential causes behind the apparent negative influence of exports on Chinese economic growth. I pose two potential explanations to these results: a decrease in trade with developed consumer economies potentially due to the growth of populism, or an increase in trade with developing nations beyond the point of efficiency as China seeks to expand its sphere of influence. These reasons are not mutually exclusive, so it could be that both phenomena are in effect. I regress the share and growth of China's exports and net exports with developed and developing nations, and find that over the past 25 years, trade with developed countries has accounted for a continually smaller share of total Chinese exports as the growth of net exports with those nations has stagnated over time. While the share of exports to underdeveloped nations has risen conversely, the growth of exports and net exports with those economies have not exhibited a significant change. These results suggest that the first theory (decreased trade with developed countries) is the principal factor behind the negative impact of trade in China.

Section II discusses China's economic transformation and the function of the open market in China's economic growth, including the policies that drove the growth of exports over the past three decades. It will also contextualize the economic development and standing of sub-Saharan Africa as a region, noting countries that have had varying levels of success in convergence. Section III presents empirical findings and regressions of export levels and economic growth in sub-Saharan Africa, and Section IV presents a very similar analysis but of provincial-level Chinese data. Section $\mathrm{V}$ is a discussion of the results of the regressions and analyses that contextualizes the findings and offers potential explanations. Section VI concludes by noting the policy implications of my findings, including ramifications for both China and sub-Saharan Africa.

\section{Development of Economies through Exports}

While China's vast natural and human resources offer explanations as to how China was able to expand its GDP at such a high rate compared to other countries, other developing nations have sought to emulate certain aspects of their economic growth. Deng Xiaoping's initiatives to liberalize trade while bolstering internal manufacturing capabilities, such as the creation of "special economic zones" (SEZ), introduced Chinese goods to international markets. China quickly became a major exporter and is now the world's largest exporter of goods and services since 2009 . In the 1990s, the Chinese government began to recognize that the inefficiency of their financial system and outdated capital stock were limiting their output capabilities. They began to expose their previously protected state-owned enterprises and banks to international competition, forcing these institutions to quickly modernize and adapt to the international standard of efficient production. The Chinese government also engaged themselves with the World Trade Organization, committing to improving their financial and industrial infrastructure as the WTO worked to remove tariffs and other barriers and allow them to trade more freely with WTO members. Through these liberalization policies, China has generated sustained levels of high economic growth, with average annual GDP growth of 9.54\% from 1992-2019.

Sub-Saharan Africa has been one of the poorest regions in the world for decades, with nearly all of its 46 countries classified as low-income, developing economies by the United Nations. The 1980s was a particularly bad decade for the region, as many countries experienced low or negative GDP growth, financial crises, mounting debt, and decreasing competition (Ackah and Morrissey, 2005). In the 1990s, sub-Saharan as a region sought to revitalize economies and spur economic growth, prompting liberalization of trade policy among African countries and globally. In 1995, the first sub-Saharan African nations joined the World Trade Organization, and 38 more countries would join in the next five years. While some countries were able to improve their domestic production through exposure to international markets and increased access to foreign direct investment, others developed dependencies on imports from large exporting nations such as China. I investigate if those sub-Saharan African countries who became net exporters in the 1990s and 2000's experienced higher economic growth during those periods. 
This study tests a model known as the export-led growth hypothesis, which poses that the growth of exports is a key predictor of total economic growth for developing nations. The theory uses the growth or level of exports as an indicator of the development of production for a nation as they substitute domestically manufactured goods for imports. In accordance with this hypothesis, the liberalization of trade is usually a key step for governments who wish to grow their economies, but in the short run, this newfound trade openness often increases trade deficits as there are even more opportunities to import products. Export-led growth is a widely discussed model among economists, but significant doubt exists as to the strength and directionality of causation with exports and growth, especially in studies that exclude the role of imports (Riezman, et. al, 1996; Xu, 1996). Some argue that the model is limited by certain factors of the country in question, such as natural resources, infrastructure, and human capital (Njikam 2003). Furthermore, there are questions as to how far the model extends as countries develop and converge. Will exports continue to drive economic growth even after a country has reached the status of a developed, middle- to high-income nation? Marin (1992) contends that the export-led growth theory cannot be disproven for industrialized nations such as the United States, Japan, and Germany, concluding that "outward looking" economic regimes generate productivity and growth in developed nations as well as underdeveloped ones. However, those countries have been developed and industrialized for over a century as opposed to the very recent shift in the makeup of the Chinese economy. Shan and Sun (1998) find empirical evidence of bidirectional causality between exports and industrial output in China, contradicting the traditional hypothesis of unidirectional impact. This additional contention to the hypothesis suggests that a country's initial efforts to stimulate exports will be doubly rewarded as the resulting rise in output will drive further growth of exports. The empirical data from individual Chinese provinces presented here will not only determine the overall legitimacy of the export-led growth hypothesis throughout its growth but also evaluate the association between exports and growth in recent years after China was firmly established as a developed economy.

\section{Sub-Saharan Africa Regressions}

These regressions relate the percentage of annual real GDP comprised of exports, imports, and net exports (x/GDP) with the annual real GDP growth for 41 sub-Saharan African nations. The data is from the Penn World Table 9.1 and covers the years 1991 through 2019. As shown in columns (1) and (5), the share of exports is significantly associated with GDP growth by a coefficient of 0.086 , while the share of net exports exhibits a significant association of 0.068 . These coefficients suggest that a $10 \%(0.1)$ increase in the share of exports would lead to a 0.86 percentage-point rise in output growth, while a $10 \%$ increase in the share of net exports would cause a 0.68 percentage-point rise in economic output growth. The share of imports does not show a statistically significant effect on GDP growth. These initial results seem to satisfy the export-led growth hypothesis, as larger contributions to GDP by both exports and net exports are associated with faster economic growth. Both of these relationships retain their statistical significance when the time variable is controlled.

To further the significance of these initial findings and search for causality, I conducted an instrumental variable estimation using membership in the World Trade Organization as an instrument. Becoming a member of the WTO is an important step towards getting involved in international trade markets, as the agreement lifts significant barriers and tariffs that inhibit free trade. A government's pursuit of WTO membership shows that they are committed to policy that liberalizes trade, and often indicates that a country is seeking to create export-led growth. Therefore, WTO membership seems to be an appropriate instrument to create exogenous variation in the X variable, the share of exports/net exports. The instrumental $\mathrm{Z}$ variable-a binary value representing WTO membership-is regressed with X as the response variable to create a new set of values, called $X_{\text {hat }}$. This new set of predicted share of exports or net exports is calculated by the regression equation in terms of the $\mathrm{Z}$ variable. The $\mathrm{X}_{\text {hat }}$ values are then regressed with the response variable Y, or GDP growth. The relationships between both the share of exports and net exports proved to be robust to the instrumental variable estimation. The data shows that countries who were members of the WTO in any given year had a $4.37 \%$ higher contribution to GDP from net exports than those years in which countries were not members and a $2.08 \%$ higher contribution from imports alone. Consequently, imports were on average $2.29 \%$ lower 
for members, suggesting that the strategy of joining trade agreements to reduce dependence on imports could be effective. The regression between predicted share of net exports and GDP growth yielded a coefficient of 0.58, while the share of exports with GDP growth had a coefficient of 2.26 (Columns (6) and (2)). These regressions predict that an increase in the share of net exports by $10 \%$ would be accompanied by a $5.8 \%$ rise in the level of GDP growth, and a $10 \%$ increase in the share of net exports would lead to a $22.6 \%$ rise in GDP growth. As shown in column (4), the IV regression for imports relates the share of imports to GDP growth by a coefficient of -0.740 , suggesting a 7.4 percentage-point increase in economic growth would follow an increase of $10 \%$ to the share of imports. The size of these coefficients is inflated by the small difference in predicted exports, imports, and net exports between countries that are and aren't WTO members. However, all three IV regressions have similar results to their corresponding OLS regressions, providing further evidence to those outcomes.

Table 1: Effect of Trade on Economic Growth in Sub-Saharan Africa

\begin{tabular}{|c|c|c|c|c|c|c|}
\hline Independent Variable: & (1) & (2) & (3) & (4) & (5) & (6) \\
\hline & $\begin{array}{l}\text { Share of Ex- } \\
\text { ports in GDP }\end{array}$ & $\begin{array}{l}\text { Share of Ex- } \\
\text { ports in GDP }\end{array}$ & $\begin{array}{l}\text { Share of Im- } \\
\text { ports in GDP }\end{array}$ & $\begin{array}{l}\text { Share of Im- } \\
\text { ports in GDP }\end{array}$ & $\begin{array}{l}\text { Share of Net } \\
\text { Exports in } \\
\text { GDP }\end{array}$ & $\begin{array}{l}\text { Share of Net } \\
\text { Exports in } \\
\text { GDP }\end{array}$ \\
\hline Specification Type: & OLS & IV & OLS & IV & OLS & IV \\
\hline \multirow[t]{2}{*}{ GDP growth } & $0.086 * * *$ & $2.258 * *$ & 0.023 & $-0.740 * * *$ & $0.068 * * *$ & $0.558 * * *$ \\
\hline & $(0.019)$ & $(0.122)$ & $(0.020)$ & $(0.051)$ & $(0.020)$ & $(0.175)$ \\
\hline Years of Data & 1991-2017 & 1991-2017 & 1991-2017 & $1991-2017$ & 1991-2017 & 1991-2017 \\
\hline Data Level & Country & Country & Country & Country & Country & Country \\
\hline Observations & 1,242 & 1,107 & 1,242 & 1,107 & 1,242 & 1,107 \\
\hline
\end{tabular}

** Denotes significance at $2.5 \%$ level; *** Denotes significance at $1 \%$ level

\section{Chinese Provincial Regressions}

The empirical data used to analyze the economic growth in China comes from each of the 30 individual Chinese provinces. This is done not only to increase the robustness of my findings by including more data points but also to see that any economic growth we are observing is not limited to any one region or community type. The data used is from the National Bureau of Statistics of China and stretches from 1994 to 2019. The initial regressions run with this data are very similar to those preliminary relationships observed with the sub-Saharan African data. To display the same measurement as was observed with the African data, I divide the value given by the database of exports/imports of "Operating Units" by GRP. This calculates the percentage of GRP comprised of exports, imports, and net exports.

As shown in column (1), the regression between the share of exports and growth of gross regional product yields a statistically significant coefficient of -0.150 , suggesting that a $10 \%$ increase in exports would lead to a 1.5 percentage-point increase in GRP growth. This association stands up when the variable time is added as a control variable. The share of net exports also has a statistically significant negative relationship with GRP growth, with a coefficient of -0.036 (Column (5)). The negative coefficients associating the share of both exports and net exports with GRP growth stand in contrast to the results of the regressions with sub-Saharan Africa, where, as an increased contribution to GRP from exports are now observed to slow down economic growth. Column (3) shows the significant 
association between the share of imports and GRP growth with a coefficient of -0.066 , indicating that an increase of $10 \%$ in imports would lead to a 0.66 percentage-point decrease in GRP growth. These initial regressions suggest that all international trade, both imports and exports, lead to decreases in economic growth.

The robustness of this result is evaluated using another instrumental variable estimation. In this case, we use the Chinese government-designated Free Trade Zones (FTZ) as an instrument. The first FTZ was established in 2013 in the city of Shanghai, offering specialized regulations that reduce import duties and increase the efficiency of shipping to businesses that operate there. The government often singles out provinces that it believes require aid for their development to become these free trade zones. Provinces that are given this designation often become hotspots for imports and exports as barriers are removed and international trade is encouraged. The Free Trade Zones serve as an appropriate instrument to create exogenous variation in the share of exports, and their binary $1 / 0$ value will function exactly as the WTO membership variable did.

I also introduce two control variables to these instrumental regressions, the natural log of GRP and an indicator that denotes whether or not a province has coastline on the ocean. As I mentioned, the Chinese government specifically targets regions and provinces that are ripe for economic development and the expansion of international trade. Especially in 2017 and later, the majority of the designations are given to poorer, more developing, and less industrialized economies as opposed to the initial designations of large commercial centers such as Shanghai and Guangdong. To limit the effect of the overall economic standing of each province on the effectiveness of the FTZs in creating trade and economic growth, I control for the natural log of GRP by year in the instrumental regression. The binary variable of whether or not a province has coastline on the Pacific Ocean is another variable that could potentially hide or alter the true effects of the FTZs on trade. The vast majority of China's international trade is conducted overseas in some way, giving coastal regions a significant advantage over inland provinces in their ability to generate export-led growth. While both coastal and landlocked provinces are included as FTZs, I control for this variable to ensure that the exogenous variation in the share of exports is created solely by the instrumental variable of the Free Trade Zones.

After controlling for these two variables, the FTZs prove to be a statistically significant instrument of the share of exports, with FTZs receiving a higher contribution to GRP from exports. The association between Predicted Share of Exports and GRP growth yields a coefficient of -0.35 , as shown in column (2). This result is consistent with that of the initial regression, indicating that increased contributions to GRP from exports as a result of the FTZs lead to decreased GRP growth. For the share of imports in GRP, FTZs are observed to be a fairly significant source of exogenous variation with a P-value of 0.046 , and FTZ status is positively associated with the share of imports in GRP. Column (5) shows that the regression of Predicted Share of Imports versus GRP growth gives a coefficient of -0.756. Both of these instrumental regressions are statistically significant to the standard level of $\mathrm{p} \leq 0.05$, corroborating the implications of the initial regressions that increased international trade decreases economic growth among China's individual provinces.

Table 2: Effect of Trade on Economic Growth in Chinese Provinces

\begin{tabular}{ccccccc}
\hline Independent Variable: & $(1)$ & $(2)$ & $(3)$ & $(4)$ & (5) & $(6)$ \\
& $\begin{array}{c}\text { Share of Ex- } \\
\text { ports }\end{array}$ & $\begin{array}{c}\text { Share of Ex- } \\
\text { ports }\end{array}$ & $\begin{array}{c}\text { Share of Im- } \\
\text { ports }\end{array}$ & $\begin{array}{c}\text { Share of Im- } \\
\text { ports }\end{array}$ & $\begin{array}{c}\text { Share of Net } \\
\text { Exports }\end{array}$ & $\begin{array}{c}\text { Share of Net } \\
\text { Exports }\end{array}$ \\
\hline Specification Type: & OLS & IV & OLS & IV & OLS & IV \\
\hline GRP growth & $-0.150^{* * *}$ & $-0.350^{* * *}$ & $-0.066^{* * *}$ & $-0.756^{* * *}$ & $-0.036^{*}$ & -0.092 \\
Standard Error: & $(0.017)$ & $(0.032)$ & $(0.013)$ & $(0.047)$ & $(0.019)$ & $(0.139)$ \\
\hline
\end{tabular}




\begin{tabular}{ccccccc} 
Years of Data & $1994-2017$ & $1994-2019$ & $1994-2017$ & $1994-2019$ & $1994-2017$ & $1994-2017$ \\
Data Level & Province & Province & Province & Province & Province & Province \\
Observations & 740 & 802 & 740 & 802 & 740 & 802 \\
\hline
\end{tabular}

*** Denotes significance at $1 \%$ level; * Denotes significance at $5 \%$ level;

\section{Discussion}

The direct and instrumental regressions between imports and exports as a share of GDP and GDP growth for subSaharan African nations and Chinese provinces produce contrasting results. While increased imports in both cases led to decreases in GDP growth, exports had two very different effects on economic growth. In the case of the developing region of sub-Saharan Africa, I find evidence that the export-led growth hypothesis is accurate: countries in which exports comprise a larger share of GDP experience higher levels of economic growth and faster convergence overall. In the mid-1990s, as many African nations attempted to expose their economies to international markets at the same time, different countries varied greatly in their ability to reduce their reliance on exports and develop consistent trade surpluses. Those countries which were able to rapidly advance their production capabilities and begin exporting at a higher rate were rewarded with faster economic development: an increase in the share of exports in GDP by 10 percentage points predicted an increase in GDP growth of $0.85 \%$ for that year, a much-needed increase for dozens of low-income nations.

The more novel results came from the Chinese regressions, which offered evidence that an increase in international trade going either way, imports or exports, could be detrimental to economic growth. With China holding the title as the world's biggest trader and the world's fastest-growing economy, this result may not make sense on the surface, but there are several logical potential explanations for this result, and they are not necessarily mutually exclusive.

\section{Trade Wars/Tariffs}

In only the past few years, China has become something of a political target for populist and even nationalist politicians across the world. As China continues to improve its infrastructure and expand its production capabilities, an alarm has been raised among conservative leaders such as Donald Trump that increased globalism in trade leads to the flight of jobs from wealthy consumer countries such as the US and that the Chinese will flood the market with inexpensive imports that will put domestic producers out of business. Trump's pledges to bring back major manufacturers and blue-collar jobs to America struck a chord among voters both in the US and abroad, as he and others such as Boris Johnson began a protectionist movement of levying significant tariffs against Chinese exporters. As China pushes for increased free trade and liberalization agreements, Xi Jinping has felt stiff resistance from Trump, Johnson, and Indian Prime Minister Narendra Modi, another nationalist who refused to join the Regional Comprehensive Economic Partnership (RCEP) and has stated that increased trade with China will hurt his country's development. As China has become a tool for populist leaders to demonstrate the harmful effects of globalism, trade wars have begun and tariffs have increased. These tariffs levied against China by large importing nations across the world could potentially have significantly decreased the efficiency of international trade, as these nations comprise far too large a portion of consumption of Chinese exports for a major redirection of trade to be sustainable. In the instrumental regressions of exports for the provincial Chinese data, the negative coefficient shows that higher levels of exports as a result of the establishment of Free Trade Zones lead to lower levels of economic growth. The first of these Free Trade Zones was established in 2013 to promote international trade and globalization, making it quite plausible that a nationalist, 
isolationist retaliation to China's market power as an exporter could cause a decline in the productivity and efficiency of international trade involving China.

\section{Sphere of Influence}

Another potential explanation for decreased yield of economic growth from exports is that the motivations for trade were not purely profit-driven. As Chinese companies have invested more and more into developing countries in South Asia and sub-Saharan Africa, many politicians and others have speculated that their intentions may be to expand the Chinese sphere of influence over these developing countries as opposed to tapping into profitable markets. Through foreign direct investment, infusions of capital, and increased infrastructure allowing for trade, Chinese businesses and banks have made their economic presence felt in the developing world as the foremost non-Western economic power. However, the majority of these countries do not yet have enough wealth for consumer bases to be reliable nor the infrastructure to facilitate large-scale trade, meaning importing into these countries could cause declines in profit margins and overall efficiency of trade. Nonetheless, China has continued to build strong trade relationships with several of these developing nations. Whether it is to build strong economic relationships for the future when these countries do become hot consumer markets or in hopes that favorable trade policy will gain them an ally in foreign policy, China may be sacrificing economic efficiency and trade efficiency in a deliberate attempt to gain economic or political influence over poor and developing nations.

In order to determine which of these factors contributed to my results, I regressed the share and growth of China's exports to developed and developing nations against time. As shown in column (1), the share of exports to developed economies has a significant association with time of -0.0041 ; this means that the share of Chinese exports to countries the United Nations deems "developed" has decreased an average of 0.4 percentage-points every year since 1994. The share of exports to developing countries has increased accordingly by the same coefficient. The growth of the natural $\log$ of total exports to developed countries has a statistically significant association of -0.00035 to time, and the level of net exports has a coefficient of -0.0014 (Columns (3) and (5)). This stagnation in the growth of trade with developed countries provides evidence to the first explanation that China's inability to reach wealthy, consumerdriven economies has been detrimental to their economic growth. The growth of exports and net exports to developing nations did not exhibit a statistically significant relationship with time, further suggesting that China's weakening export relationships with other global powers is the driving force behind my initial findings.

Table 3: Chinese Exports to Economically Developed and Developing Nations Over Time

\begin{tabular}{lcccccc}
\hline Dependent Variable: & $(1)$ & $(2)$ & $(3)$ & $(4)$ & $(5)$ & $(6)$ \\
& $\begin{array}{l}\text { Share of Ex- } \\
\text { ports to De- } \\
\text { veloped } \\
\text { Countries }\end{array}$ & $\begin{array}{c}\text { Share of Ex- } \\
\text { ports to Devel- } \\
\text { oping Coun- } \\
\text { tries }\end{array}$ & $\begin{array}{c}\text { Growth of } \\
\text { Exports to } \\
\text { Developed } \\
\text { Countries }\end{array}$ & $\begin{array}{c}\text { Growth of Ex- } \\
\text { ports to Devel- } \\
\text { oping Coun- } \\
\text { tries }\end{array}$ & $\begin{array}{c}\text { Exports to De- } \\
\text { veloped Coun- } \\
\text { tries }\end{array}$ & $\begin{array}{c}\text { Expowth of Net } \\
\text { oping Countries }\end{array}$ \\
\hline \multicolumn{1}{c}{ Specification Type: } & OLS & OLS & OLS & OLS & OLS & OLS \\
\hline Time (years) & $-0.0041^{*} * *$ & $0.0041 * * *$ & $-0.00035 * *$ & 0.00024 & $-0.0014 * * *$ & $7.35 \mathrm{e}-5$ \\
Standard Error: & $(7.9 \mathrm{e}-4)$ & $(7.9 \mathrm{e}-4)$ & $(1.7 \mathrm{e}-4)$ & $(2.2 \mathrm{e}-4)$ & $(3.2 \mathrm{e}-4)$ & $(2.7 \mathrm{e}-4)$ \\
\hline Years of Data & $1994-2018$ & $1994-2018$ & $1994-2018$ & $1994-2018$ & $1994-2018$ & $1994-2018$ \\
Data Level & Country & Country & Country & Country & Country & Country \\
Observations & 25 & 25 & 25 & 25 & 25 & 25
\end{tabular}


*** Denotes significance at $1 \%$ level; * Denotes significance at $5 \%$ level;

\section{Conclusion}

Although China's rapid economic growth and convergence is largely attributed to domestic production and exportled growth, it may be time to reevaluate whether or not an export-based economy is still the most efficient strategy going forward. While the export-led growth hypothesis may apply to those countries who are still in the midst of development such as those of sub-Saharan Africa, its effects seem to diminish once a country has nearly completed its transition to a middle- to high-income, developed economy. Unless China can convince the Western consumer world of its good intentions in trade or somehow recover lost efficiency in trade by targeting different markets, this evidence suggests that its economic growth will stagnate.

As for sub-Saharan Africa, this data suggests that the export-led growth model is valid for those countries that are developing. However, a problem is presented in that as African countries trade with each other, it is nearly impossible for a majority to maintain a consistent trade surplus as is prescribed. Further removal of barriers, both policy-oriented and logistical, to intercontinental trade between Africa and the rest of the world as those countries continue to industrialize will be key to revitalizing a region mired in poverty and economic challenges.

\section{Acknowledgments}

I would like to thank my advisor Brian Wheaton for his mentorship and guidance throughout the project. I would also like to thank Polygence and its staff for their help in completing this process.

\section{References}

Ackah, C., \& Morrissey, O. (2005). Trade policy and performance in sub-Saharan Africa since the 1980s. https://www.econstor.eu/bitstream/10419/80322/1/511131933.pdf

Riezman, R. G., Whiteman, C. H., \& Summers, P. M. (1996). The engine of growth or its handmaiden?. In LongRun Economic Growth (pp. 77-110). Physica-Verlag HD.

http://content.ebscohost.com/Content-

Server.asp?T=P\&P=AN\&K=6758132\&S=R\&D=buh\&EbscoContent=dGJyMNXb4kSeqLU4yNfsOLCmsEmeqLFS r664SbWWxWXS\&ContentCustomer=dGJyMPGsr0\%2Bup7VIuePfgeyx44Dt6fIA

$\mathrm{Xu}, \mathrm{Z}$. (1996). On the causality between export growth and GDP growth: an empirical reinvestigation. Review of International Economics, 4(2), 172-184. https://doi.org/10.1111/j.1467-9396.1996.tb00094.X

Njikam, O. (2003). Exports and economic growth in Sub-Saharan Africa: Is there a connection. Faculty of Economics \& Management. University of Yaoundé II, Yaoundé. https://citeseerx.ist.psu.edu/viewdoc/download?doi=10.1.1.548.1405\&rep=rep1\&type=pdf

Marin, D. (1992). Is the export-led growth hypothesis valid for industrialized countries?. The Review of Economics and Statistics, 678-688. https://www.jstor.org/stable/pdf/2109382

Shan, J., \& Sun, F. (1998). On the export-led growth hypothesis: the econometric evidence from China. Applied Economics, 30(8), 1055-1065. https://doi.org/10.1080/000368498325228 